\title{
SEED PHYSICAL SCARIFICATION AND GROWING MEDIA ON VIGOR OF Moringa oleifera
}

\author{
Ubaidillah, A. V. Zulaiha, dan R Dianita*) \\ The Faculty of Animal Science, University of Jambi \\ *) corresponding author: rahmi_dianita@yahoo.com
}

\begin{abstract}
This experiment was aimed to reveal the effect of seed physical scarification and various growing media on vigor of Moringa oleifera. This study was conducted in greenhouse and consisted of two phases of experiment; first was studied the effect of physical scarification on seed germination of M. oleifera and the second was studied the effect of seed physical scarification and various sub optimum growing media on vigor of $M$. oleifera. The germination test was arranged in randomized completely design with 4 treatments that were $\mathrm{Po}=$ non scarification, $\mathrm{P}_{1}=$ one side scarification, $\mathrm{P}_{2}=$ two sides scarification, and $\mathrm{P}_{3}=$ full side scarification. The variables measured were germination percentage (\%) and seedling dry weight (g/plant). The second study was arranged in a factorial randomized completely design with the four treatments of scarification (Po, P1, P2 and $\mathrm{P}_{3}$ ) over six growing media (sands, bricks, bricks and sands mixture, bricks and soils mixture, soils and sands mixture, and soils). The variables observed were petioles number, plant height $(\mathrm{cm} /$ plant), and plant dry weight $(\mathrm{g} /$ plant $)$. The scarification was significantly affect $(\mathrm{P}<0.05)$ the germination percentage and seedling dry weight. Scarification and growing media also affected the vigor of $M$. oleifera significantly $(\mathrm{P}<0.05)$. Two side seed scarification improve the germination and seedling dry weight instead of control. Combination of scarification in two sides and growing media of soils and sands mixture given the highest vigor of $M$. oleifera reflected on petioles number, plant height, and plant dry weight.
\end{abstract}

Keywords: germination, M. oleifera, scarification, sub optimum media, vigor

\section{SKARIFIKASI FISIK BENIH DAN BERBAGAI MEDIA TANAM TERHADAP VIGOR MORINGA OLEIFERA}

\begin{abstract}
ABSTRAK
Penelitian ini bertujuan untuk mengetahui pengaruh skarifikasi fisik benih dan berbagai media tanam terhadap vigor Moringa oleifera. Penelitian ini dilakukan di rumah kaca dan terdiri dari dua fase percobaan; pertama adalah penelitian tentang pengaruh skarifikasi fisik terhadap perkecambahan benih $M$. oleifera dan yang kedua penelitian tentang pengaruh skarifikasi fisik benih dan berbagai media tanam sub optimum terhadap vigor $M$. oleifera. Uji perkecambahan disusun dalam rancangan acak lengkap dengan 4 perlakuan yaitu $\mathrm{Po}=$ non skarifikasi, $\mathrm{P}_{1}=$ skarifikasi satu sisi, $\mathrm{P}_{2}=$ skarifikasi dua sisi, dan $\mathrm{P}_{3}=$ skarifikasi sisi penuh. Variabel yang diukur adalah persentase perkecambahan (\%) dan berat kering kecambah (g/tanaman). Penelitian kedua didesain dalam rancangan acak lengkap faktorial dengan empat perlakuan skarifikasi (Po, P1, P2, dan P3) pada enam media tanam (pasir, batu bata, campuran batubata dan pasir, campuran batubata dan tanah, campuran batubata dan tanah, campuran tanah dan pasir, dan tanah). Variabel yang diamati adalah jumlah tangkai, tinggi tanaman (cm/tanaman), dan berat kering tanaman (g/tanaman). Skarifikasi secara signifikan mempengaruhi $(\mathrm{P}<0,05)$ persentase perkecambahan dan berat kering kecambah. Skarifikasi dan media tanam juga mempengaruhi vigooritas $M$. oleifera secara signifikan $(\mathrm{P}<0,05)$. Skarifikasi dua sisi benih meningkatkan daya kecambah dan bobot kering kecambah. Kombinasi skarifikasi pada dua sisi benih dan media tanam campuran tanah dan pasir memberikan vigoritas $M$. oleifera tertinggi dicerminkan dari jumlah tangkai, tinggi tanaman, dan berat kering tanaman.
\end{abstract}

Kata kunci: perkecambahan, $M$. oleifera, skarifikasi, media sub optimum, vigoritas 


\section{INTRODUCTION}

Moringa oleifera is a nutritious legume species which often used in malnutrition cases and also has medicinal purposes (phytochemical content). Dried leaves of $M$. oleifera contained $30.29 \%$ of crude protein, $6.50 \%$ of fat, 7.64 of ash, $11.40 \%$ of NDF, $8.48 \%$ of ADF, $1.8 \%$ of lignin, $4.01 \%$ of cellulose, $3.12 \mathrm{mg} / \mathrm{g}$ of condensed tannins, $2.02 \%$ of total polyphenols and with 19 amino acids. The highest value of the amino acids was alanine, which had a value of $3.033 \%$ and the least content was cysteine with 0.01\% (Moyo et al., 2011). Based on this fact, nutrient characterization of Moringa indicated that this plant leaves has potential to be used as a feed additive with multiple purposes such as for human and animal feed formulations.

Some research has been done and focus on potential use of Moringa in several aspects such as medicinal value, nutrition, chemistry, pharmacological properties, commercial product development and also physiology. Less study about cultivation of Moringa exist. $M$. oleifera can be cultivated and developed from both generative and vegetative material. Seed of $M$. oleifera as generative material has a unique form. The seed has three sides just like triangular cubes with unique wing-like structures. The seed coat is a little bit hard and it may takes some days to germinate. Moringa seeds are quite tender, but as soon as they get dried, they become hard and start resembling small beans (Thaher et al., 2017). Ponnuswami (2018) found that the seed of $M$. oleifera germinates 10 to 12 days after sowing. Physical dormancy is caused by water impermeable layers of palisade cells in the seed or fruit coat that control water movement. Mechanical or chemical scarification can break the physical dormancy (William et al., 2006).

Seed mechanical/physical scarification is a technique to physically damage the seed coat to reduce hard seed while keeping the seed viable. According to Kimura and Islam (2012) important methods of seed scarification include heat, freeze-thaw, mechanical / physical and acid scarification. For mechanical scarification, many researchers have used mechanical scarifiers or sand papers to rub the seed manually. The purpose of mechanical/physical scarification is to allow the water and oxygen enter the seed while germination stage by thinning out the seed peel. This condition will enhance the seed to germinate. Mechanical scarification could greatly reduce germination time of Laucaena leucocephala (Lam) as most seeds sprouted (87.5\%) in the first 4 days and germination was complete by day 7 whilst the hot water, dry heat and sulphuric acid treatments had 14,5 and $3.25 \%$ germination count respectively by day 4 (Koobonye et al., 2018). Seed germination also has a direct impact on productivity of the plant. Biotic and abiotic factors can both affect seed germination and productivity (Bhardwaj, 2014).

Abiotic factor like growing media for the plant will affect the development and later maintenance of the extensive functional rooting system. Growing media also plays an important role in seed germination, seedling growth and vigor (Dayeswari et al., 2017). A good growing medium would provide sufficient support to the plant, serves a reservoir of nutrients and water, allow oxygen diffusion to the root, and permit gaseous exchange between the root and atmosphere outside the root substrate (Abad et al., 2002). Media composition used influence the quality of seedling due to physical, chemical and biological properties (Wilson et al., 2001).

A vigor test is to propose to better express of seed physiological potential, mainly under suboptimal conditions. Thus, mechanical/physical scarification and various sub optimum growing media treatment were studied to enhance seed vigor of $M$. oleifera.

\section{MATERIALS AND METHODS}

This study was carried out in greenhouse in Forages and Crops Research Station at the Faculty of Animal Science, University of Jambi. There was no automatic temperature adjustment in the glass house. The ambient temperature inside glass house will be affected by the outside temperature. The seed of Moringa oleifera used in the test was taken from Moringa garden in local community. The mature seed were harvested two weeks and dried in greenhouse before experiment. The seed stored at ambient temperature around $28-30^{\circ} \mathrm{C}$ before seedling. The seed moisture determined by oven method $\left(105^{\circ} \mathrm{C}\right.$ for $\left.24 \mathrm{~h}\right)$. The seed weight was $0.2 \mathrm{~g} / \mathrm{seed}$ in average.

The germination test conducted by using petri dish with diameter of $10 \mathrm{~cm}$ contained 25 seeds represent one treatment. The seed sown on a $3 \mathrm{~cm}$ cotton moistened with aqua destilation. It placed in plastic transparent growth chamber in glass house. There were 4 treatments and 4 replicates which was arranged in randomized completely design. Seedling emergence was investigated with physical scarification treatments (non scarification, one side, two side, full side of seed scarification). Seedling emergence was evaluated on day 12 after seed sowing, and the seedling was taken from the cotton media for seedling dry weight measurement.

Three samples of each treatment taken and grown in various growing media (six growing media) by using nursery pot to assess the plant vigor. This experiment was arranged in factorial randomized completely design $(4 \times 6)$. The first factor was physical scarifica- 
tion (non scarification, one side, two side, full side of seed scarification). The second factor was sub optimum growing media which consisted of sands, bricks (grounded in to fine particle), bricks and sands mixture, bricks and soils mixture, soils and sands mixture, and soils (ultisol soils). The ration of mixture growing media was $1: 1$. The seed germination percentage (SGP) measured by using the equation: SGP = number of germinated seeds over total seed planted. Petioles number counted per plant. Plant height was measured in centimeters using a tape measure. Seedling dry weight and plant dry weight were measured at oven $60^{\circ} \mathrm{C}$ during 2 days.

The collected data were analysed by using the SPSS (version 22.0) software package. The means were compared with Duncan's Multiple Range Test (DMRT).

\section{RESULTS AND DISCUSSIONS}

\section{Seed Germination}

Scarification significantly affect $(\mathrm{P}<0.05)$ the seed germination and also seedling dry weight. Non scarification seed had the highest germination percentage but it was not significantly difference ( $\mathrm{P}>0.05$ ) with one side scarification. As well as the germination percentage, the highest seedling dry weight found at non scarification seed but it was not different $(\mathrm{P}>0.05)$ with two side scarification. The lowest germination percentage and seedling dry weight found in full side scarification.

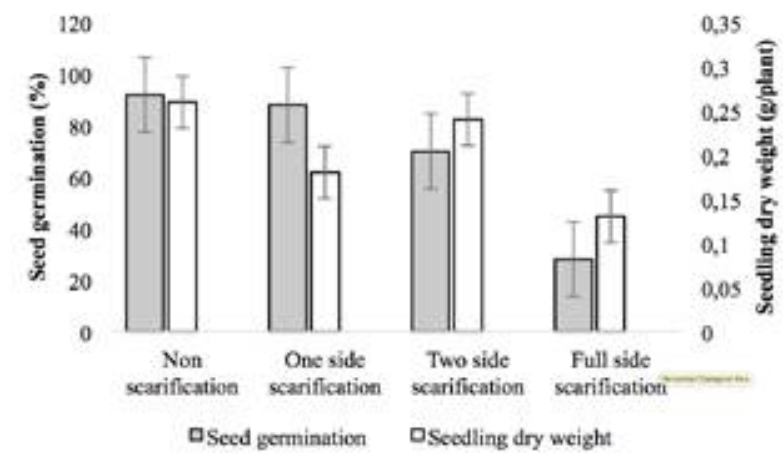

Figure 1. Seed germination and seedling dry weight as effect of physical scarification

Seed germination test conducted in growth chamber lied in glass house. The temperature in growth chamber might reach $34^{\circ} \mathrm{C}$ at noon. The seed coat surface in full side scarification treatment scratch wider than other treatments (control, one side and two side scarification). The gasses and water entry and permit easily from the micropyle. The exposure to this unfavorable condition in glass house affected the seed condition and resulted to low germination percentage (Figure 1). Seed exposure to unfavorable environmental conditions might cause serious degenerative changes in metabolic activities. This condition also affect the growth of seedling. Seedling dry weight of full side scarification seed was lowest than other treatments. Many factors can affect seed viability such as the ability of the plant to produce viable seeds, predator and pathogen damage, and environmental conditions like flooding or heat (Shaban, 2013). Marcos-Filho (2015) added that initial seed aging is the decline in germination speed of viable seeds followed by a decrease in seedling size, and an increased incidence of abnormal seedlings (although the primary root protrusion rate should remained high).

\section{Seed Vigor}

Seed performance in seedling phase affect the growth of plant in nursery. Seed germination percentage and seedling dry weight were important toward the plant vigor. Koobonye et al. (2018) stated that a high germination performance can aid in successful field establishment and/or maintenance of readily-available plant stock in nurseries.

The characteristics of sub optimum media in this study that sand was more porous, brick (fine particle) was compact, and soil (ultisol soil) was slightly compact when it showered with water. The result in this study showed that overall the mixture growing media with sands (bricks+sands and soils+sands) with scarification performed the good vigor growth of M. oleifera (Table 1). Supplementing sands in to the media make the growth media more porous (Bhardwaj, 2014). Soil and sands medium was the most suitable medium for shoot and leaf growth of banana (Ratna et al., 2006).

The result of seed vigor was relevant to seed germination whereas the seed with wide surface of scars (full side scarification) had lower vigor (petioles number, plant height and plant dry weight) compared to other treatments. In addition, the plants might not perform it capacity well in sub optimum growing media, especially for bricks, bricks+soils, and soils media. Two side scarification with the mixture growing media with sands (soils+sands) demonstrated the highest vigor. The structure of growing medium must be soft and porous enough so the root can easily penetrate widely in to the material and it must also provide support for the plant (Asiah et al., 2004). Seed vigor is an interaction of characteristics the independent attributes of physiological potential such as speed of germination, seedling growth, ability to germinate above or below optimal temperatures, and other aspects of tolerance to stresses (Macros-Filho, 2015). The delay in emergence resulted in under 
Table 1. Vigor of M. oleifera as Effect of Physical Scarification and Growing Media

\begin{tabular}{|c|c|c|c|c|c|}
\hline \multirow[b]{2}{*}{$\begin{array}{l}\text { Growing } \\
\text { Media }\end{array}$} & \multicolumn{4}{|c|}{ Physical Scarification } & \multirow[b]{2}{*}{ SEM } \\
\hline & $\begin{array}{c}\text { Non } \\
\text { scarification }\end{array}$ & One side & Two side & Full side & \\
\hline & \multicolumn{4}{|c|}{ Petioles number } & \\
\hline Sands & $13.667^{\mathrm{b}}$ & $17.000^{\mathrm{a}}$ & $17.333^{\mathrm{a}}$ & $16.333^{\mathrm{ab}}$ & \\
\hline Bricks & $13.667^{\mathrm{c}}$ & $16.333^{\mathrm{ab}}$ & $18.000^{\mathrm{a}}$ & $15.000^{\mathrm{bc}}$ & \\
\hline Bricks + sands & $14.667^{\mathrm{b}}$ & $19.333^{\mathrm{a}}$ & $18.667^{\mathrm{a}}$ & $16.000^{\mathrm{b}}$ & 1.876 \\
\hline Bricks + soils & $13 \cdot 333^{\mathrm{b}}$ & $15.667^{\mathrm{b}}$ & $19.333^{\mathrm{a}}$ & $15.000^{b}$ & \\
\hline Soils + sands & $19.333^{\mathrm{a}}$ & $17.667^{\mathrm{ab}}$ & $18.667^{\mathrm{a}}$ & $14.333^{\mathrm{b}}$ & \\
\hline \multirow[t]{2}{*}{ Soils } & $16.000^{\mathrm{bc}}$ & $17 \cdot 333^{\mathrm{ab}}$ & $19.000^{\mathrm{a}}$ & $13.667^{\mathrm{c}}$ & \\
\hline & \multicolumn{4}{|c|}{ Plant height $(\mathrm{cm})$} & \\
\hline Sands & $15 \cdot 46^{\mathrm{b}}$ & $21.77^{\mathrm{b}}$ & $19.37^{\mathrm{a}}$ & $16.25^{\mathrm{a}}$ & \\
\hline Bricks & $16.47^{\mathrm{b}}$ & $18.00^{b}$ & $21.17^{\mathrm{a}}$ & $17.90^{\mathrm{b}}$ & \\
\hline Bricks + sands & $18.33^{\mathrm{ab}}$ & $19.70^{\mathrm{a}}$ & $19.27^{\mathrm{a}}$ & $17 \cdot 5 \mathrm{O}^{\mathrm{b}}$ & 2.075 \\
\hline Bricks + soils & $18.07^{\mathrm{ab}}$ & $12.43^{\mathrm{c}}$ & $20.47^{\mathrm{a}}$ & $17.17^{\mathrm{b}}$ & \\
\hline Soils + Ssnds & $20.37^{\mathrm{ab}}$ & $22.50^{\mathrm{a}}$ & $19.83^{\mathrm{ab}}$ & $17.55^{\mathrm{b}}$ & \\
\hline \multirow[t]{2}{*}{ Soils } & $20.33^{\mathrm{a}}$ & $17.07^{\mathrm{b}}$ & $21.40^{\mathrm{a}}$ & $16.05^{\mathrm{b}}$ & \\
\hline & \multicolumn{4}{|c|}{ Plant dry weight (g/plant) } & \\
\hline Sands & $0.303^{b}$ & $0.493^{\mathrm{a}}$ & $0.460^{\mathrm{a}}$ & $0.245^{\mathrm{b}}$ & \\
\hline Bricks & $0.327^{\mathrm{ab}}$ & $0.210^{b}$ & $0.420^{\mathrm{a}}$ & $0.265^{\mathrm{b}}$ & \\
\hline Bricks + sands & $0.320^{\mathrm{a}}$ & $0.313^{\mathrm{a}}$ & $0.290^{\mathrm{a}}$ & $0.220^{b}$ & 0.003 \\
\hline Bricks + soils & $0.290^{\mathrm{a}}$ & $0.297^{\mathrm{a}}$ & $0.307^{\mathrm{a}}$ & $0.320^{\mathrm{a}}$ & \\
\hline Soils + sands & $0.337^{\mathrm{b}}$ & $0.497^{\mathrm{a}}$ & $0.517^{\mathrm{a}}$ & $0.310^{b}$ & \\
\hline Soils & $0.337^{\mathrm{a}}$ & $0.323^{\mathrm{a}}$ & $0.320^{\mathrm{a}}$ & $0.320^{\mathrm{a}}$ & \\
\hline
\end{tabular}

$a, b, c)$ Means followed by different superscript in the same rows are significantly different at $(P<0.05)$ by Duncan Multiple Range Test

development of at all the stage of the plant growth as compared to high vigor seed (Kandasamy et al., 2020)

\section{CONCLUSION}

This study demonstrated that two side scarification was the best treatment for seedling emergence of $M$. oleifera seed. Two side scarification seed with soils and sands media performed the best vigor which reflected in petioles number, plant height and plant dry weight.

\section{REFERENCES}

Abad M, P. Noguera, R. Puchades, A. Maquieira, V. Noguera. 2002. Physico-chemical and chemical properties of some coconut coir dusts for use as a peat substitute for containerised ornamental plants. BioresourceTechnology. 82(3): 241-245

Al-Barakah and Sohaib. 2019. Evaluating the germination response of Chenopodium quinoa seeds to bacterial inoculation under different germination media and salinity conditions. Seed Science and Technology, 47 (2): 161-169.

Asiah A, M. Razi, M. Y. Khanif, M. Marziah, M. Shaharuddin. 2004. Physical and chemical properties of coconut choir dust and oil palm empty fruit bunch and the growth of hybrid heat tolerant Cauliflower plant. J. Trop. Agric. Sci. 27(2): 121 - 133

Bhardwaj R. L. 2014. Effect of growing media on seed germination and seedling growth of papaya cv. 'Red lady'. African Journal of Plant Science 8(4): $178-184$.

Dayeswari D, S. Rayaprolu and A. Jone. 2017. Effect of Potting Media on Seed Germination, Seedling Growth and Vigour in TNAU Papaya Co.8 (Carica papaya L.). Int. J. Pure App. Biosci. 5 (3): 505-512

Kandasamy S, N. Weerasuriya, D. Gritsiouk, G. Patterson, S. Saldias, S. Ali, and G. Lazarovits. 2020. Size Variability in Seed Lot Impact Seed Nutritional Balance, Seedling Vigor, Microbial Composition and Plant Performance of Common Corn Hybrids. J.of Agronomy 10, 157

Kimura E. and Islam M. A. Seed scarification methods and their use in forage legumes. Research Journal of Seed Science 5: 38-50.

Koobonye M, B. V. Maule, and K. Mogotsi. 2018. Mechanichal scarification and hot water treatments enhance germination of Laucaena leucocephala (Lam.) seeds.Livestock Research for Rural Development 3 (1).

Marcos-Filho J. 2015. Seed vigor testing: an overview of the past, present and future perspective. Sci. Agric. 72, (4): 363-374

Moyo B, Patrick J. M, Arnold H. Voster M. Nutritional characterization of Moringa (Moringa oleifera Lam.) leaves. African Journal of Biotechnology 10 (6o): 12925-12933. http://www. academicjournals.org/AJB.

Ponnuswami V. Advance in Production of Moringa. Horticultural College \& Research Institute, Tamil Nadu Agricultural University Periyakulam 625 604, Tamil Nadu. India.

Ratna T. E, A. Awaludin, dan H Sutanto. 2006. The effect of media on the growth of Pisang Susu plant origin Bonggol in Sambelia, East Lombok. J. Hortikultura 1: 15-22

Shaban M. 2013. Study on some aspects of seed viability and vigor. International Journal of Advanced Biological and Biomedical Research 1 (12): 1692-1697

Taher M. A, Abu M. B. N, Ahammed. MD. M, Hossain MD. M, Islam M. N. 2017 Moringa oleifera (Shajna): the wonderful indigenous medicinal plant. Asian J. Med. Biol. Res. 3 (1): 20-30.

William E, F. Savage and G. L.Metzger. 2006. Seed dormancy and the control of germination. Tansley Review. New Phytologist.. 171: 501-523

Wilson F. B. Stoffella P. J, Graets D. A. 2001. Use of compost as media amendment to containerized production of two subtropical perennials. J. Environ. Hortic. 19: 37-4 